\title{
A CONSTRUÇÃO HERMENÊUTICA DO MANDADO DE INJUNÇÃO PELO SUPREMO TRIBUNAL FEDERAL SOB A ÓTICA DO PRINCÍPIO DA SEPARAÇÃO DOS PODERES E DO ATIVISMO JUDICIAL
}

Ana Cláudia de Medeiros Franklin ${ }^{97}$

Recebido em: 05/04/2018

Aprovado em: 28/05/2018

\begin{abstract}
RESUMO
O presente trabalho busca promover uma análise constitucional do Mandado de Injunção remédio instituído para viabilizar o exercício de direitos e liberdades constitucionais assegurados por normas constitucionais de eficácia limitada que se encontrem obstaculizado pela omissão legislativa em editar norma regulamentadora. Nesse passo, intenta-se observar o processo de construção dos efeitos que foram conferidos pelo Supremo Tribunal Federal através das decisões concessivas de Mandado de Injunção, traçando breve estudo sobre o instituto e as correntes interpretativas que sobre ele dispõem, bem como evidenciando a atual posição concretista adotada pelo STF. Em decorrência disso, será apreciado o suposto conflito entre os princípios da separação dos poderes e da efetividade da constituição, em razão do ativismo adotado pelo judiciário que é acusado de usurpar a função legislativa ao exercer função política. Trata-se de um estudo bibliográfico, doutrinário, com breve análise jurisprudencial que, por fim, intenta analisar a relevância do ativismo judicial no processo de efetividade conferido ao Mandado de Injunção que viabiliza, por consequência, efetividade à própria Constituição. Conclui-se que o ativismo judicial surte efeitos positivos no ordenamento jurídico, desde que respeite os limites impostos pela Constituição, sob pena de ao invés de remediar a omissão legislativa tornar-se um problema.
\end{abstract}

Palavras-chave: Mandado de Injunção; Omissão Constitucional; Ativismo Judicial.

\section{INTRODUÇÃO}

A Constituição de 1988 ao ser criada contrapondo-se à sistemática negação de direitos constitucionais vivenciados na ditadura militar promoveu uma ampla garantia de direitos

\footnotetext{
${ }^{97}$ Mestranda em Direito Constitucional pela Universidade Federal do Rio Grande do Norte (UFRN). Advogada.
} 
fundamentais outrora negligenciados e, analiticamente, conferiu sede constitucional a matérias que guardariam maior adequação em normas infraconstitucionais.

Em consequência disso, muitas normas constitucionais foram criadas com eficácia limitada, de modo que mesmo resguardadas pela Constituição carecem de complemento normativo para efetivar os seus efeitos, isto é, só produzem efeito mediante a atuação de atividade legiferante incumbida de promover a devida regulamentando do desígnio constitucional.

O constituinte originário, preocupado em respeitar o anseio social e em promover uma real efetivação das normas e dos direitos constitucionais, não se olvidou em garantir que as sobreditas leis de eficácia limitada fossem devidamente regulamentadas no plano infraconstitucional e a fim de combater a mora dos poderes competentes criou o Mandado de Injunção no bojo da Constituição Federal de 1988.

Tal ferramenta, disposta no art. $5^{\circ}$, LXXI da CRFB/88, trata-se de ação constitucional disponibilizada aos indivíduos como instrumento de combate a ineficácia e violação de normas constitucionais que resguardam direito e princípios fundamentais, em decorrência da omissão do Poder Público em regulamenta-las devidamente ${ }^{98}$.

A natureza jurídica do instrumento processual estudado é de controle difuso, que tem como finalidade precípua permitir o livre desempenho de determinado direito fundamental, presumido eficaz, mas cujo exercício torna-se impossibilitado pela omissão do poder público em prestar a providência necessária de que ele depende.

Quando foi instituído, o Mandado de Injunção tratava-se de novidade nunca antes vista seio jurídico suscitando diversos questionamentos especialmente acerca dos limites impostos à prestação jurisdicional, já que a própria CRFB/88 não dispôs sobre a forma que o remédio deveria ser aplicado.

Ironicamente, mesmo sendo eminentemente necessário, a regulamentação específica na esfera infraconstitucional do remédio estudado só ocorreu no ano de 2016 com a promulgação da Lei n ${ }^{\circ}$ 13.300/2016, também denominada de Lei do Mandado de Injunção, instituída para disciplinar sobre o tramite processual e o julgamento do Mandado de Injunção. Até então, os Mandados de Injunção vinham sendo julgados de acordo com uma interpretação analógica dos procedimentos presentes na Lei do Mandado de Segurança.

Antes da devida regulamentação, vários Mandados de Injunções foram impetrados para sanar omissões legais cabendo ao Supremo Tribunal Federal (STF) o papel de

\footnotetext{
${ }^{98}$ GUERRA FILHO, Willis Santiago. Processo constitucional e direitos fundamentais. São Paulo: RCS Editora, 2009, p. 153.
} 
regulamentar a forma como o remédio constitucional deveria se comportar, tanto no aspecto processual como até mesmo seus efeitos. Desse modo, através de uma construção hermenêutica, o referido Tribunal percorreu diversos posicionamentos até conceber o atual entendimento adotado acerca da forma como o Mandado de Injunção iria surtir seus efeitos.

Nos seus primeiros julgados, o STF adotava a denominada posição não concretista que entendia não caber ao judiciário prover a omissão indicada ou determinar que fosse suprida pelo legislativo, sob o argumento de que estaria violando o princípio da separação dos poderes. Nesse ínterim, a demanda injuncional terminava não surtindo nenhum efeito concreto para o suplicante, o que acabava por esvaziar a eficácia do remédio constitucional em tela.

Ciente disso, em 2007, o STF lançou nova interpretação sobre o instituto adotando a posição concretista. Nesses termos, o Tribunal passou a assumir posição ativa em suprir a omissão legislativa com o fito de possibilitar o exercício dos direitos e liberdades preservados pela Constituição ao jurisdicionado.

Assim, a fim de conferir real efetividade ao Mandado de Injunção, o STF ampliou a interpretação da norma constitucional de modo a suprir a morosidade legislativa que inibia o exercício de direitos constitucionais, constituindo hialino exemplo de judicialização de questões eminentemente políticas e de ativismo judicial.

Todavia, muito se questiona se ao adotar tal posicionamento de flagrante ativismo judicial, o STF não acabaria atuando como legislador positivo de modo a extrapolar sua competência e invadir a dos outros poderes com uma consequente violação ao princípio da separação de poderes.

Nessa toada, o presente trabalho tem como fito observar se o STF, ao atuar ativamente conferindo efeito concretista ao Mandado de Injunção, não acaba olvidando o princípio da separação de poderes, observando a pertinência da adoção de tal postura pelo STF na consecução de efetividade ao instituto do Mandado de Injunção e, por conseguinte, da vontade da Constituição.

O estudo será pautado pelo estudo bibliográfico, doutrinário com breve análise jurisprudencial acerca das teorias relativas com o supedâneo de evidenciar a modificação de orientação do STF acerca do Mandado de Injunção, a fim de concluir se a nova interpretação dada ao remédio constitucional analisado atinge ou não o princípio da separação de poderes, concluindo com a relevância do ativismo judicial para a eficácia das normas constitucionais. 


\section{A CONSTRUÇÃO HERMENEUTICA DO INSTITUTO DO MANDADO DE INJUNÇÃO PELO STF}

O Mandado de Injunção consiste em uma inovação introduzida pela Constituição Federal de 1988 como reação ao problema de ineficiência das normas constitucionais que consiste, para a maioria da doutrina, em uma verdadeira criação do ordenamento jurídico brasileiro, pois não há exemplar semelhante no direito comparado ${ }^{99}$.

Assim, nos termos do art. 5, LXXI, o Mandado de Injunção foi designado como um instrumento hábil a conferir eficácia as normas garantidoras de direitos e liberdades constitucionais que, devido a omissão legislativa, deixam de ser aplicadas e não cumprem sua real finalidade por necessitarem de norma regulamentadora no plano infraconstitucional para produzir os efeitos desejados.

$\mathrm{O}$ art. $2^{\circ}$, da Lei 13.300/2016, regulamentou o instituto dispondo que "conceder-se-á mandado de injunção sempre que a falta total ou parcial de norma regulamentadora torne inviável o exercício dos direitos e liberdades constitucionais e das prerrogativas inerentes à nacionalidade, à soberania e à cidadania".

Em outras palavras, o Mandado de Injunção é um remédio constitucional mandamental que, mediante lacuna legislativa, tem por escopo promover a implementação do exercício de direitos e liberdades constitucionais e de prerrogativas inerentes à nacionalidade, à soberania e à cidadania ${ }^{100}$.

Tratando-se de ação especial de controle concreto que tutela direito subjetivo, o instrumento processual tem como objeto o não cumprimento de um dever constitucional de legislar que pode acabar prejudicando direitos constitucionalmente assegurados ${ }^{101}$. De tal modo, o grande desígnio do pedido injuncional consiste em regulamentar a norma para o caso concreto, de forma temporária, enquanto não for sanada a omissão ${ }^{102}$.

\footnotetext{
${ }^{99}$ CUNHA JÚNIOR, Dirley da. Controle judicial das omissões do poder público: em busca de uma dogmática constitucional transformadora à luz do direito fundamental à efetividade da Constituição. 2. ed. rev. e atual. São Paulo: Saraiva, 2008, p. 532.

100 JÚNIOR, Paulo Hamilton Siqueira. Direito processual constitucional. São Paulo: Editora Saraiva, 2008, p. 363.

${ }^{101}$ MENDES, Gilmar Ferreira. Curso de Direito Constitucional. 2. ed. rev. e atual. São Paulo, Saraiva, 2008/ BARROSO, Luís Roberto. O direito constitucional e a efetividade de suas normas. 9. ed. Rio de Janeiro: Renovar, 2009, p. 1207.

102 BARROSO, Luís Roberto. Constituição, Democracia e Supremacia judicial: Direito e Política no Brasil Contemporâneo. Revista Jurídica da Presidência. Brasília, vol. 12, n. 96, Fev/Mai, 2010. Disponível em: <http://www.luisrobertobarroso.com.br/wpcontent/uploads/2017/09/constituicao_democracia_e_supremacia_judicial.pdf >. Acesso em 28 de março 2018.
} 
Está-se diante de ação constitucional que pode ser promovida por qualquer sujeito de direito que se considere tolhido do exercício de direitos constitucionalmente previstos em decorrência da falta de norma regulamentadora exigida pela Constituição Federal ${ }^{103}$. Essa ausência regulatória pode ser total ou parcial que, nos termos do art. $2^{\circ}$, parágrafo único, da Lei do Mandado de Injunção, ocorre quando "as regulamentações forem insuficientes as normas editadas pelo órgão legislador competente".

Impele destacar que a legitimidade do Mandado de Injunção é universal, podendo qualquer pessoa que deseje implementar a norma constitucional ser titular do writ. Contudo, o remédio só surte seus efeitos para o pretenso caso concreto, ou seja, não tem efeitos erga omnes, exceto se for destinado a uma coletividade no denominado Mandado de Injunção Coletivo, muito utilizado para amparar demandas de direito trabalhista.

Nesse caso, mesmo que não tenha sido expressamente insculpido na CFRB/1988, tal modalidade do remédio é admitido a partir de uma interpretação sistemática da Constituição conferida pelo STF que tomou como base o art. $5^{\circ}, \S 2^{\circ}$, da Carta Magna, quando diz que "os direitos e garantias expressos nesta Constituição não excluem outros decorrentes do regime e dos princípios por ela adotados, ou dos tratados internacionais em que a República Federativa do Brasil seja parte".

Face ao exposto, pode-se observar que o Mandado de Injunção ainda é um instituto que precisa ser esmiunçado se comparado com os demais remédios constitucionais, pois ainda se trata de um enigma à ser totalmente compreendido. $\mathrm{O}$ vazio vislumbrado relaciona-se a brevidade e imprecisão com que o dispositivo constitucional regulamenta o presente writ sem delimitar precisamente seu objeto ou direcionar como a norma deve ser interpretada, como fruto disso, o que se conhece atualmente sobre o mesmo é fruto da construção jurisprudencial $^{104}$.

Desde a sua instituição na Constituição Federal de 1988, o Mandado de Injunção só recebeu regulação própria no ano de 2016 com da Lei $n^{\circ}$ 13.300/2016 que disciplinou o processo e o julgamento de tal remédio constitucional na modalidade individual e coletiva.

Uma relevante inovação advinda com a nova lei foi a regulamentação do Mandado de Injunção Coletivo que, embora viesse sendo admitido pelo STF, não foi previsto pela Constituição Federal de 1988. Com isso, o mandado de injunção passou a ser distinguido em duas categorias: coletivo e individual.

\footnotetext{
${ }^{103}$ SILVA, José Afonso da. Curso de direito constitucional positivo. 11 ed. São Paulo: Malheiros, 1996, p. 426.

${ }^{104}$ GUERRA FILHO, Willis Santiago. Processo constitucional e direitos fundamentais. São Paulo: RCS Editora, 2009, p. 157.
} 
Assim, nos termos do art. 12 da Lei do Mandado de Injunção "os direitos, as liberdades e as prerrogativas protegidos por mandado de injunção coletivo são os pertencentes, indistintamente, a uma coletividade indeterminada de pessoas ou determinada por grupo, classe ou categoria", podendo ser proposto por legitimados taxativamente estipulados.

Opostamente, o Mandado de Injunção Individual destina-se a suprir o direito de pessoa natural e a jurídica que foram mitigados pela omissão em suas liberdades ou prerrogativas específicas relacionadas à soberania, à cidadania ou à nacionalidade, sendo essa espécie de mandado de injunção o objeto do presente estudo.

Nada obstante, antes da vigência da Lei do Mandado de Injunção, coube ao STF, enquanto responsável pela interpretação da Constituição, o papel de definir os efeitos provocados Mandado de Injunção. A primeira leitura dada ao instituto ocorreu em 1989 no julgamento do Mandado de Injunção $\mathrm{n}^{\circ}$ 107-DF, quando decidiu que a ação se destinava apenas a declarar a mora em editar o regulamento pleiteado pelos autores.

EMENTA: - Mandado de injunção. Estabilidade de servidor público militar. Artigo 42, parágrafo 9., da Constituição Federal. Falta de legitimação para agir. Esta Corte, recentemente, ao julgar o mandado de injunção 188, decidiu por unanimidade que só tem "legitimatio ad causam", em se tratando de mandado de injunção, quem pertença a categoria a que a Constituição Federal haja outorgado abstratamente um direito, cujo exercício esteja obstado por omissão com mora na regulamentação daquele. - Em se tratando, como se trata, de servidores públicos militares, não lhes concedeu a Constituição Federal direito a estabilidade, cujo exercício dependa de regulamentação desse direito, mas, ao contrário, determinou que a lei disponha sobre a estabilidade dos servidores públicos militares, estabelecendo quais os requisitos que estes devem preencher para que adquiram tal direito. - Precedente do STF: MI 235. Mandado de injunção não conhecido: (STF - MI: 107 DF, Relator: MOREIRA ALVES, Data de Julgamento: 21/11/1990, TRIBUNAL PLENO, Data de Publicação: DJ 02-08-1991 PP-09916 EMENT VOL-01627-01 PP-00001 RTJ VOL-00135-01 PP-00001)

De lá para cá, relevante foi o papel desempenhado pelo STF na construção hermenêutica no sentido de definir os efeitos do instituto estudado, não sendo por menos que é no tocante aos efeitos da decisão julgadora do Mandado de Injunção que circundam as maiores controvérsias e debates hermenêuticos, tanto na doutrina quanto na jurisprudência. Dispondo sobre tal tema, existem duas grandes correntes: a não concretista e a concretista, essa que se subdivide em geral e intermediária.

\subsection{TEORIA NÃO CONCRETISTA}


A corrente não concretista filia-se a ideia de que o julgamento pelo Tribunal tem papel meramente declaratório ou mandamental, no sentido de que a decisão proferida no bojo do Mandado de Injunção deve apenas declarar formalmente a omissão legislativa e cientificar o órgão ou poder competente do seu próprio estado de indolência a fim de que promova a complementação normativa ${ }^{105}$.

O maior argumento em prol dessa corrente consiste na observância ao princípio da separação dos poderes, consagrado no art. $2^{\circ}$ da CRFB/88, segundo o qual o Poder Judiciário não poderia sanar a lacuna legislativa, pois estaria suprimindo a função dos outros poderes do Estado se agisse como legislador positivo.

De acordo com Hely Lopes Meirelles, o judiciário não pode legislar pelo Congresso Nacional, pois, a Constituição preservou a independência dos Poderes como dispõe o seu art. $34, \S 2^{\circ}$. Diante disso, ao julgar um Mandado de Injunção, o Tribunal deve determinar que a autoridade impetrada tome as providências cabíveis ${ }^{106}$.

O Ministro Celso de Melo ao proferir seu voto no MI 107/DF, aduziu que:

O Mandado de Injunção não é o sucedâneo constitucional das funções políticojurídicas atribuídas aos órgãos estatais inadimplentes. Não legitima, por isso mesmo, a veiculação de provimentos normativos que se destinem a substituir a faltante norma regulamentadora sujeita à competência, não exercida, dos órgãos públicos. $\mathrm{O}$ STF não se substitui ao legislador ou ao administrador que se hajam abstido de exercer a sua competência normatizadora. A própria excepcionalidade desse novo instrumento jurídico impõe ao Judiciário o dever de estrita observância do princípio constitucional da divisão funcional do Poder.

Assim, com caráter notadamente mais conservador, tal corrente foi adotada pelo STF nas suas primeiras decisões relativas aos efeitos dos Mandando de Injunção ${ }^{107}$, porém tais decisões eram alvos de inúmeras críticas, dentre elas está o fato de tal interpretação tornar os efeitos do Mandado de Injunção a Ação de Inconstitucionalidade por Omissão (ADO), própria do controle de constitucionalidade.

Segundo pode-se depreender dos ensinamentos de Flávia Piovesan, se os preceitos da interpretação concretista realmente refletissem a vontade do legislador originário, não existiria

\footnotetext{
${ }^{105}$ DANTAS, Paulo Roberto de Figueiredo. Direito processual constitucional. 2. ed. São Paulo: Atlas, 2010, p. 369.

${ }^{106}$ MEIRELLES, Hely Lopes. Mandado de Segurança. 31 ed. São Paulo: Malheiros, 2008, p. 265.

${ }^{107}$ Em que pese a predominância da corrente concretistas, o STF proferiu algumas decisões com inclinação mais concretista, como por exemplo no Mandado de Injunção $n^{\circ}$ 232/RJ, que suscitava a necessidade de suprimento da omissão em regular o art. $195, \S 7^{\circ}$, da Constituição Federal, decidindo que, após seis meses sem a edição da lei regulamentadora, a requerente poderia gozar da imunidade requerida.
} 
razão para a existência de dois institutos constitucionais com idêntica finalidade, sob pena de atentar a logicidade e coerência do sistema constitucional ${ }^{108}$.

Outra crítica pertinente é que a teoria não concretista acabava por esvaziar o instituto do Mandando de Injunção ante a sua inefetividade, pois não supria a pretensão do autor prejudicado ante a omissão legislativa inviabilizando o exercício de seus direitos fundamentais.

Nessa toada, a providencia jurisdicional do Mandado de Injunção expressava-se inócua, pois, não parecia com um mandato, já que só podia cientificar o órgão omisso e conscientemente letárgico, nem tão pouco detinha característica injuntiva, vez que mais exercia o papel de influenciar a criação da norma do que obrigar que o jurisdicionado efetivamente percebesse seus efeitos legais.

Frente a isso, ao longo dos anos, o STF atualizou a doutrina não concretista de modo que, além de declarar a omissão legislativa, passou a estipular prazo para edição da norma necessária, e se o legislador permanecesse inerte, ficava aludida a parte a obter seu direito na primeira instância, mas com decisão surtindo efeito inter partes ${ }^{109}$.

Embora tal entendimento represente avanço, ainda não era o bastante para elidir o problema de inefetividade hermeneuticamente imposto ao remédio constitucional, levandonos a concluir que a corrente não concretista não representa o melhor entendimento que deve ser direcionado ao remédio constitucional analisado.

\subsection{TEORIA CONCRETISTA}

Para a teoria concretista a decisão que julga o Mandado de Injunção adquire um caráter constitutivo, de sorte que, além de declarar a omissão inconstitucional do órgão competente pela formulação da lei, também assume a função de concretizar o direito fundamental negligenciado.

Assim, a atividade jurisdicional acaba por implementar a norma a fim de viabilizar o exercício de prerrogativa ou direito tutelado pela Constituição Federal que restava carente de regulamentação, até que o órgão competente preencha a lacuna legal existente.

\footnotetext{
${ }^{108}$ PIOVESAN, Flávia C. Proteção judicial contra omissões legislativas: ação direta de inconstitucionalidade por omissão e mandado de injunção. São Paulo: Editora Revista dos Tribunais, 1995, 129.

109 À exemplo tem-se os julgados dos MI 283, MI 284 e MI 232.
} 
Destaque-se que a teoria concretista se subdivide em três correntes, quais sejam a geral, individual e intermediária. Tais correntes dispõe o modus operandi da atividade concretista adotadas pelos Ministros do Supremo Tribunal Federal.

A teoria concretista individual, entende que a decisão judicial permitirá a fruição do direito com efeitos inter partes, ou seja, sem alcançar aqueles que não componham o polo ativo da ação injuncional. Logo, mediante a procedência do Mandado de Injunção, desde logo, o impetrante pode já pode sentir os efeitos da eficácia da norma constitucional, possibilitando o exercício do direito.

Tal posicionamento é defendido por grande parte da doutrina e foi adotado pelo STF inúmeras vezes como, por exemplo, no Mandado de Injunção $n^{\circ}$ 721-DF que visava regular o art. $40, \S^{\circ}$, III da Constituição Federal em que se julgou procedente o pedido formulado pelo impetrante, onde foi concedido o direito do servidor público à contagem do tempo de serviço para fins de aposentadoria especial pelo exercício de atividade insalubre (CF, art. 40, § $\left.{ }^{\circ}, \mathrm{III}\right)$.

\begin{abstract}
MANDADO DE INJUNÇÃO - NATUREZA. Conforme disposto no inciso LXXI do artigo $5^{\circ}$ da Constituição Federal, conceder-se-á mandado de injunção quando necessário ao exercício dos direitos e liberdades constitucionais e das prerrogativas inerentes à nacionalidade, à soberania e à cidadania. Há ação mandamental e não simplesmente declaratória de omissão. A carga de declaração não é objeto da impetração, mas premissa da ordem a ser formalizada. MANDADO DE INJUNÇÃO - DECISÃO - BALIZAS. Tratando-se de processo subjetivo, a decisão possui eficácia considerada a relação jurídica nele revelada. APOSENTADORIA TRABALHO EM CONDIÇÕES ESPECIAIS - PREJUÍZO À SAÚDE DO SERVIDOR - INEXISTÊNCIA DE LEI COMPLEMENTAR - ARTIGO 40, § $4^{\circ}$, DA CONSTITUIÇÃO FEDERAL. Inexistente a disciplina específica da aposentadoria especial do servidor, impõe-se a adoção, via pronunciamento judicial, daquela própria aos trabalhadores em geral - artigo $57, \S 1^{\circ}$, da Lei $n^{\circ} 8.213 / 91$ (STF/MI 721-DF).
\end{abstract}

A teoria concretista geral, a decisão judicial reconhece a mora legislativa e concretiza o direito constitucional obstaculizado, que pode ser através do uso de analogia de norma equivalente com efeitos erga omnes até que a atividade legiferante supra a lacuna existente.

O STF filiou-se a essa corrente através do julgamento de Mandados de Injunção interpostos com o supedâneo de regularizar o direito de greve dos servidores públicos, resguardado pelo art. 37, VII da Constituição Federal que ainda não foi regulamentado por lei específica e foi objeto dos Mandados de Injunção $n^{\circ}$ 670/ES ${ }^{110}, 708 / \mathrm{DF}^{111}$ e 712/PA ${ }^{112}$, a

\footnotetext{
${ }^{110}$ O Mandado de Injunção foi impetrado pelo Sindicato dos Servidores Policiais Civis do Espírito Santo (Sindpol).

${ }^{111}$ Mandado de Injunção impetrado pelo Sindicato dos Trabalhadores em Educação de João Pessoa (Sintem).

${ }^{112}$ Mandado de Injunção impetrado pelo Sindicato dos Trabalhadores do Poder Judiciário do Pará (Sinjep).
} 
partir de quando o Tribunal modificou seu entendimento inclinando-se para a teoria concretista.

Ressalte-se que a questão da greve dos servidores públicos já havia sido alvo de discursão tendo sido apreciada pelo STF desde o julgamento do Mandado de Injunção $\mathrm{n}^{\circ} 20$. Á época, o Tribunal adotando a teoria não concretista declarou a omissão legislativa em virtude de a matéria nunca ter recebido regulamentação por parte do Congresso Nacional.

Frente ao estágio de letargia assumida pelo Poder Legislativo, não restou alternativa ao Poder Judiciário senão suprir hermeneuticamente o direito de milhares de servidores públicos que viram seu direito de greve padecer por anos ante a inexistência de norma jurídica que viabilizasse o seu exercício, vez que um direito constitucionalmente resguardado não pode ser sucateado em decorrência da inércia voluntaria do Poder Legislativo.

Foi nos autos do Mandado de Injunção no 670/ES, com julgamento em 25 de outubro de 2007, que se observou uma evolução jurisprudencial no entendimento daquela Corte decidindo pela maioria pelo suprimento da omissão constitucional com a aplicação das regras previstas para o setor privado (Lei $n^{\circ} 7.783 / 89$ ), enquanto não for elaborada a regulamentação especifica.

Na ocasião, o Ministro Celso de Mello, ao proferir seu voto, afirmou que não era aceitável e razoável a falta de regulamentação do direito de greve no serviço público por parte do Congresso Nacional. Avaliou o ministro que é dever do STF dar efetividade às cláusulas constitucionais e que, no caso, "a inércia arrasta consigo a descrença na Constituição Federal”.

De tal sorte, a guinada jurisprudencial assumida pelo STF significou expressivo avanço na tutela de direitos e liberdades com guarita constitucional, já que se tornou instrumento efetivo para a sua perfectibilizarão dos preceitos constitucionais.

Por fim, tem-se a teoria concretista intermediaria dispondo que, inicialmente, deve o poder judiciário cientificar ao órgão responsável pela normatização sobre a sua mora, de modo a estipular um prazo a omissão seja suprimida. Porém, se após o termino do prazo o órgão permanecer omisso, cumpre ao Juízo o dever de suprir os efeitos negativos da lacuna legal, oportunizando o exercício do direito constitucional postulado que pode ter efeitos tanto erga omnes ou inter partes, o que varia à cada caso. Nessa toada, tem-se que essa corrente agrada a maioria da doutrina por tentar conciliar os princípios da separação das funções com outros constantes do texto constitucional. 


\begin{abstract}
julgamento do Mandado de Injunção n. 107 com possibilidade de aplicação de providencias adicionais nele genericamente admitidas, e concretizadas no julgamento do Mandado de Injunção n. 283. - O prazo fixado, no julgamento do Mandado de Injunção n. 283, para o cumprimento do dever constitucional de editar essa regulamentação de há muito se escoou sem que a omissão tenha sido suprida. Não há, pois, razão para se conceder novo prazo ao Congresso Nacional para o adimplemento desse seu dever constitucional, impondo-se, desde logo, que se assegure aos impetrantes a possibilidade de ajuizarem, com base no direito comum, ação de perdas e danos para se ressarcirem do prejuízo que tenha sofrido. Mandado de injunção conhecido em parte, e nela deferido." (STF - MI: 447/DF, Relator: MOREIRA ALVES, Data de Julgamento: 05/05/1994, TRIBUNAL DO PLENO, Data da Publicação: DJ 01-07-1994 PP-17495 EMENT VOL-01751-01 PP-00038)
\end{abstract}

A partir da edição da Lei 13.300/2016, em seu art. $8^{\circ}$, a corrente concretista intermediária é adotada como regra pelo nosso ordenamento jurídico, pois autoriza o Judiciário a estabelecer prazo para que seja editada a norma regulamentadora, fornecendo maneiras e condições em que atribuirá o exercício dos direitos, liberdades ou prerrogativas exigidos ou as formas que poderá o lesado intentar ação própria afim de exercê-los, caso a ausência de regulamentação legislativa não for suprida no prazo proposto.

Nesse palco, não se pode negar que, assumindo tal postura de ativismo judicial, o STF passou a desempenhar função atípica, vez que atua como legislador positivo, função que é própria do Poder Legislativo.

Face a isso, pertinente se demonstra averiguar se, ao conferir concretude aos Mandados de Injunção, o STF não estaria realmente usurpando a função que a constituição outorgou para outros poderes de maneira a macular o princípio da separação dos poderes. Para tanto, necessário se faz observar o papel do ativismo judicial nesse processo com o fito de concluir se os efeitos que tal dinâmica repercute positivamente ou negativamente no ordenamento jurídico nacional.

\title{
3 O SUPOSTO CONFLITO ENTRE O PRINCÍPIO DA SEPARAÇÃO DOS PODERES E OS PRINCÍPIOS DA SUPREMACIA E EFETIVIDADE CONSTITUCIONAL.
}

O princípio da separação dos poderes recebeu guarita constitucional, no art. $2^{\circ}$ da Carta Magna, dispondo que o Legislativo, o Executivo e o Judiciário são os três poderes que compõem o Estado, sendo tais poderes independentes e harmônicos uns em relação aos outros, com o fito de impedir a concentração de poder, vez que esses se autolimitam. 
Todavia, insta observar que a própria Constituição de 1988 abrandou a rigidez que caracterizava a divisão de funções, pois estipulou algumas exceções que permitem que os Poderes desempenhem funções atípicas, isto é, que não são próprias da sua função.

Corroborando, Gilmar Mendes aduz que o paradigma da separação dos poderes pensada na sua forma clássica entrou em crise há bastante tempo, em razão da eminente necessidade de atualização do princípio em tela com vistas a se adequar as novas demandas da sociedade aberta dos intérpretes da Constituição ${ }^{113}$.

Assim, ao adaptar-se ao moderno Estado Constitucional de Direito incorporou ideias sociais e democráticos que repercutem nas esferas do Poder inclusive no Judiciário que passou a desenvolver uma atuação política com vistas a garantir os direitos de cidadania e a concretização dos direitos fundamentais ${ }^{114}$.

Nesse palco, ao conferir efeitos concretos ao Mandado de Injunção, o STF promoveu uma ampliação do seu âmbito de atuação, de maneira a adotar uma postura eminentemente política que conduz o Tribunal atuar como legislador positivo, o que para alguns críticos extrapola as fronteiras entre os Poderes lesionando o princípio da separação dos poderes.

Porém, deve-se ressaltar que a autuação do STF por meio do Mandado de Injunção não foi uma criação desse Corte, mas da própria Constituição Federal que, em seu art. $5^{\circ}$, LXXI, criou tal remédio constitucional hábil para combater no caso concreto a negligencia de direitos fundamentais ocasionada pela inércia do legislador que, como já alhures demonstrado, trata-se de instrumento diferente da Ação Direita de Inconstitucionalidade por Omissão.

É de óbvia constatação de que quando o STF inovou sobremaneira na interpretação dada aos efeitos do Mandado de Injunção, o Tribunal não estaria fazendo outra coisa senão buscar a vontade do constituinte originário que, ciente de que a omissão legislativa poderia prejudicar a carta de direitos assegurados em 1988, deixou para o futuro um instrumento capaz de dirimir tais danos.

Assim, quando a Constituição Federal criou tal mecanismo para amparar os direitos e liberdades constitucionais, não foi para ele existisse apenas no plano formal, porquanto a escopo do constituinte foi outro se não conferir efetividade ao remédio constitucional e, por conseguinte, a norma constitucional.

Destarte, quando ampliou hermeneuticamente os efeitos do Mandado de Injunção, o STF está apenas exercendo seu papel designado pela Constituição, qual seja de protege-la

\footnotetext{
${ }^{113}$ MENDES, Gilmar Ferreira. Curso de direito constitucional. 4 ed. São Paulo: Saraiva, 2009, p. 118.

${ }^{114}$ Ibidem., p. 118-119.
} 
conferindo-a efetividade. Nesse sentido, a orientação seguida pela referida Corte consiste em concretizar o direito afiançado, no sentido de suprir a omissão inconstitucional, bem como dirimir o problema da ineficácia das normas constitucionais.

Nesse sentido, interessante lançar olhar sobre os ensinamentos de Ferdinand Lassalle que demonstra a importância da Constituição escrita não seja transformada em apenas um pedaço de papel, vez que de nada servirá o que se escreve numa folha de papel, pois, se isso ocorrer, a Constituição necessariamente sucumbirá perante a constituição real, a das verdadeiras forças vitais do país ${ }^{115}$.

Isto, posto, ao lançar uma interpretação concretista sobre o Mandado de Injunção, a Corte Superior acabou diluindo o distanciamento existente o que existia no plano constitucional no tocante a garantia do exercício dos direitos fundamentais através de um remédio constitucional - a folha de papel - e o problema de ineficiência que realmente ocorria no mundo fático, que patentemente configuravam um problema de caráter normativo no tocante a efetividade do texto constitucional.

Sobre essa temática, Konrad Hesse elaborou importante contribuição doutrinária nos ensinando que o significado da ordenação jurídica na realidade, e em face dela, somente pode ser apreciado se a ordenação e a realidade forem consideradas em sua relação, em seu inseparável contexto, e no seu condicionamento recíproco, de modo que em face da realidade, a norma constitucional não tem existência autônoma ${ }^{116}$.

A pretensão de eficácia de uma norma constitucional não se confunde com as condições de sua realização, como elemento autônomo, a pretensão de eficácia associa-se a essas condições, já que a Constituição não configura apenas expressão de um ser, mas também de um dever ser. ${ }^{117}$

Todavia, a força normativa da constituição não reside, tão-somente, na adaptação inteligente a uma dada realidade. A Constituição jurídica logra converter-se, ela mesma, em força ativa, que se assenta na natureza singular do presente. Nesse sentido, pode-se afirmar que a Constituição se torna uma força ativa se fizerem presentes na consciência geral não só a vontade de poder, como também a vontade de Constituição. ${ }^{118}$

A força que constitui a essência e a eficácia da Constituição reside na natureza das coisas, impulsionando-a, conduzindo-a e transformando-se, assim, em força ativa. De tal

\footnotetext{
${ }^{115}$ LASSALLE, Ferdinand. A essência da Constituição. Rio de Janeiro: Lumen juris, 2013, p. 37.

${ }^{116}$ HESSE, Konrad. A força normativa da Constituição. Tradução: Gilmar Ferreira Mendes. São Paulo: Editora Saraiva, 2009, p. 127.

${ }^{117}$ Ibidem., p. 126.

${ }^{118}$ Ibidem., p. 133.
} 
modo, tem-se que é daí que advém os seus limites, assim como os pressupostos que permitem à Constituição desenvolver de forma ótima a sua força normativa ${ }^{119}$.

A Carta Magna de um país possui força normativa reconhecida, que se assenta no caráter vinculativo e obrigatório de seus enunciados, ou seja, é dotada de efetividade e aplicabilidade. Assim, as normas Constitucionais não podem ser enfrentadas como mera sugestão, visto que se tratam de normas jurídicas que possui plena imperatividade, o que obriga a Corte Suprema a agir ativamente na busca efetivar, com seriedade, o seu objeto real objeto, qual seja a Constituição ${ }^{120}$.

Destarte, adotando a teoria concretista, necessário se fez promover uma interpretação teleológica e sistemática do instituto objeto de estudo, uma vez que se revela descabido que um remédio designado a luz de vetores axiológicos garantistas da CRFB/88, seja frustrado em detrimento da proteção formalista de proteção à separação dos poderes.

Ademais, ao exercer uma função política não representa dizer que o STF tenha violado o princípio da separação de inerente a dinâmica entre os três Poderes da União. Pois, na dicção de Flávia Piovesan, com o Mandado de Injunção, o Poder Judiciário não usurpa a função de legislar, já que seu papel não é a de elaborar normas, mas apenas possibilitar o exercício de direitos fundamentais no caso concreto.

Nesse passo, o Poder Judiciário está exercendo apenas sua função típica de garantir a efetivação das Constituição, muito embora que para isso tenha necessitado expandir seu âmbito de atuação ${ }^{121}$. De tal modo, pode-se afirmar que o exercício do Mandado de Injunção consiste em uma expressão dos controles mútuos entre os poderes, isto é, o denominado sistema de freios e contra freios.

Nesse palco, a interpretação concretista tomada pelo STF foi medida que se impôs, pois, o fugaz reconhecimento da inercia da atividade legiferante era insuficiente em resolver a negativa do exercício dos direitos fundamentais assegurados pela Constituição Federal olvidando precipuamente a força normativa da Constituição.

\section{A RELEVÂNCIA do ATIVISMO JUdiciáRIO PARA O MANDAdo DE INJUNÇÃO}

\footnotetext{
${ }^{119}$ Idem.

${ }^{120}$ VILANOVA, Lourival. A Dimensão Política nas funções do Supremo Tribunal Federal. In: Revista de Direito Público, p. 53.

${ }^{121}$ PIOVESAN, Flávia C. Proteção judicial contra omissões legislativas: ação direta de inconstitucionalidade por omissão e mandado de injunção. São Paulo: Editora Revista dos Tribunais, 1995, p. 151.
} 
Pelo fenômeno de judicialização do direito, tem-se que diversas questões que antes eram de atribuição própria da política foram trazidas para o âmbito de competência do Judiciário pela própria Constituição de 1988 que, assim, viabilizou a ampliação da influência do Poder.

O ativismo judicial amplia a participação do judiciário na concretização dos valores e fins constitucionais, que passam a interferir mais no espaço de atuação dos outros Poderes, mas que, muitas vezes, não há conflito entre os Poderes, vez que o judiciário vem ocupando espaços vazios $^{122}$, como demonstra a jurisprudência do Mandado de Injunção.

Nesse passo, observa-se que quando determinada temática ganha sede constitucional, ela automaticamente se torna susceptível à ser objeto de interpretação judicial pelo STF. Assim, restando satisfeitos os requisitos legais de cabimento do mandando de injunção, a Corte Suprema é instada a se manifestar em relação a determinada omissão legislativa cabendo-a exercer seu papel constitucional, qual seja de pronunciar quanto ao mérito, mesmo quando trata-se de matéria de competência de outros poderes. Assim, permite-nos elucidar o porquê do crescente processo de ativismo do assumido pelo poder judiciário.

Corroborando com tal processo, tem-se a influência negativa do cenário político brasileiro maculado por uma fatídica crise de representatividade, já que na maioria das vezes, os governantes não refletem os anseios sociais. Como reflexo disso, o judiciário acaba se expandindo para os espaços em que existia demandas sociais relevantes, mas o Legislativo se omitiu.

Nesse palco, vê-se o Poder Judiciário protagoniza um processo de crescimento do ativismo judicial caracterizado pela ampliação das funções jurisdicional provocada por uma postura de atitude do Juízo na busca pela concretização dos objetivos e valores constitucionais a fim de suprir as lacunas deixadas pelos demais Poderes da União.

Fato é que em decorrência dessa postura ativista com aplicação da teoria concretista, o Mandado de Injunção passou a surtir os efeitos almejados pelo constituinte originário, bem como superando o esvaziamento do instituto provocado pela jurisprudência balizada na teoria não concretista

Porquanto, constata-se que o ativismo judicial foi a alternativa utilizada pelo Judiciário para minorar a constate inércia legislativa conferindo palpabilidade aos direitos e liberdades constitucionais negligenciados pela ausência de normas regulamentadoras.

\footnotetext{
${ }^{122}$ BARROSO, Luís Roberto. O controle de constitucionalidade no direito brasileiro. São Paulo: Saraiva, 2016, p. 364.
} 
Destarte, relevante se faz observar o que dispõe Luiz Roberto Barroso ao aduzir que o ativismo judicial compõe, em certa medida, a solução de muitos problemas hodiernos. Porém, apesar de não ainda não ser, pode virar um problema, já que é um antibiótico poderoso que deve ser utilizado de modo eventual e comedido, pois se tornar-se excessivo pode causar consequências desastrosas ${ }^{123}$.

Logo, filiamo-nos a ideia de que o ativismo judicial consiste em atitude plausível e até necessária na garantia de direitos constitucionalmente amparados, mas que por algum motivo, o cidadão não consegue exerce-los. Contudo, releve-se que o ativismo só será saudável se respeitar os limites impostos pela própria Constituição, com o supedâneo de cair no problema da usurpação de Poderes.

Isto, pois, não se pode mais aceitar que, em pleno o Estado Democrático e após todos os ensinamentos sedimentados pelo neoconstitucionalismo, o Judiciário se restrinja a desempenhar papel interpretativo meramente subsuntivo. Opostamente, espera-se uma conduta proativa do Juízo que promova inovação da ordem jurídica e social, atendendo aos anseios da sociedade.

Todavia, é inegável que a ideia de democracia está umbilicalmente ligada a separação dos poderes, bem como a plena desenvoltura Poder Legislativo. Nessa esteira, mais do que desacreditar o Poder Legislativo ao ponto de precisar ser suprido pelo avultamento de outro poder, é necessário que o legislativo seja repensado e reestruturado para que possa assumir sua importância na dinâmica da relação de Poder.

\section{CONSIDERAÇÕES FINAIS}

A adoção do ativismo judicial trata-se de uma realidade no seio jurídico que busca assegurar o amplo exercício dos direitos fundamentais, assim como evitar que a Constituição de 1988 seja transformada em letra morta face à inércia do Poder Legislativo.

É inconteste que o juiz deve preferir uma decisão apenas com base em uma norma geral criada pelo legislador. Porém, deve-se questionar o que deve ser feito quando não existe norma geral e, mais, quando um remédio constitucional designado justamente para suprir

\footnotetext{
123 BARROSO, Luís Roberto. Constituição, Democracia e Supremacia Judicial: Direito e Política no Brasil Contemporâneo. Revista Jurídica da Presidência, Brasília, vol. 12, n. 96, Fev/Mai, 2010. Disponível em: <https://www4.planalto.gov.br/revistajuridica/vol-12-n-96-fev-mai-2010/menu-vertical/artigos/artigos.2010-0609.1628631230/?searchterm=Barroso>. Acesso em 13 de dezembro 2014, p. 274.
} 
omissões legislativa, na verdade, acaba obstando a garantir o direito pleiteado, como ocorria quando STF, ao julgar os Mandados de Injunção, filiava-se a teoria não concretista.

De tal sorte, ao direcionar efeitos concretistas aos efeitos do Mandado de Injunção o Supremo Tribunal Federal notadamente adota uma posição ativista que, além de necessária, ante ao estado de inercia voluntaria adotada pelo Legislativo que parece pouco se importar com o direito dos cidadãos, ainda corresponde a persecução do exercício de seu dever legal, qual seja de conferir ampla efetividade a Constituição.

Nesse palco, foi discutido se a conduta ativa do Judiciário não estaria extrapolando seu limite de modo a usurpar a função de outros poderes em ato atentatório ao princípio da separação de poderes. Para tanto, chegou-se à conclusão de que tal principal, apesar de extremamente relevante, não deve ser encarado de forma engessada podendo ser relativizado, como o fez a Constituição de 1988.

Destarte, tem-se que a Suprema Corte ao desempenhar atribuições política, inerente a outros Poderes do Estado, não representa dizer que viola o princípio da separação de poderes, pois, opostamente, a adoção de função política pelo Judiciário faz parte do contorno que a Constituição Federal intentou direcionar a tal princípio com o sistema de "freios e contra freios".

Outrossim, fora observado que a intenção do constituinte originário foi que o Judiciário conferisse concreção aos direitos e liberdades constitucionais, quando constatasse a mora legislativa, vez que regulamentou remédio constitucional apto à tanto.

Nesse sentido, a Constituição Federal prevendo o Mandado de Injunção almejou tornar a tornar a proteção Constitucional efetiva. De tal sorte, a interpretação inovadora com adoção de funções políticas pela Corte Suprema lançada sobre Mandado de Injunção foi o único meio que capaz de conferir efetividade a ação constitucional estudada e, por conseguinte, aos direitos do cidadão que sofria pela ausência de legislação regulamentadora no plano infraconstitucional.

Portanto, o ativismo judicial, respeitando devidamente os limites legais, trata-se de alternativa positiva para persecução da vontade da Constituição. Porém, se faz necessário que esse protagonismo do judiciário respeite os limites estabelecidos pela própria Constituição, a fim de que para resolver uns problemas, nas acabemos gerando outros caracterizado pela concentração de poder em um único órgão.

\section{REFERÊNCIAS}


BARROSO, Luís Roberto. Constituição, Democracia e Supremacia judicial: Direito e Política no Brasil Contemporâneo. Revista Jurídica da Presidência, Brasília, vol. 12, n. 96, Fev/Mai, 2010. Disponível em: < http://www.luisrobertobarroso.com.br/wpcontent/uploads/2017/09/constituicao_democracia_e_supremacia_judicial.pdf $>$. Acesso em 28 de março 2018.

BARROSO, Luís Roberto. O controle de constitucionalidade no direito brasileiro. São Paulo: Saraiva, 2016

CORRÊA, Karine Lyra. A nova interpretação do STF sobre os efeitos do mandado de injunção e o princípio da separação de poderes. Disponível em: $<$ http://www.arcos.org.br/artigos/a-nova-interpretacao-do-stf-sobre-os-efeitos-do-mandadode-injuncao-e-o-principio-da-separacao-de-poderes/\#topo>. Acesso em: 25 março 2018.

CUNHA JÚNIOR, Dirley da. Controle judicial das omissões do poder público: em busca de uma dogmática constitucional transformadora à luz do direito fundamental à efetividade da Constituição. 2. ed. rev. e atual. São Paulo, Saraiva, 2008.

DANTAS, Paulo Roberto de Figueiredo. Direito processual constitucional. 2. ed. São Paulo: Atlas, 2010.

FREITAS, Gabriela Oliveira. Ativismo judicial: Mandado de Injunção. In: Âmbito Jurídico, Rio Grande, XII, n. 69, out 2009. Disponível em: <http://www.ambitojuridico.com.br/site/index.php?n_link=revista_artigos_leitura\&artigo_id=6838>. Acesso em 4 $\operatorname{dez} 2016$.

GUERRA FILHO, Willis Santiago. Processo constitucional e direitos fundamentais. São Paulo: RCS Editora, 2009.

LASSALLE, Ferdinand. A essência da Constituição. Rio de Janeiro: Lumen juris, 2013.

HESSE, Konrad. A força normativa da Constituição. Tradução: Gilmar Ferreira Mendes. São Paulo: Editora Saraiva, 2009.

JÚNIOR, Paulo Hamilton Siqueira. Direito processual constitucional. São Paulo: Editora Saraiva, 2008.

Mandado de Injunção - um instrumento republicano para sanar eventuais omissões legislativas. Disponível em: 
<http://www.stf.jus.br/portal/cms/verNoticiaDetalhe.asp?idConteudo=165753>. Acesso em: 4 maio 2018.

MEIRELLES, Hely Lopes. Mandado de Segurança. 31 ed. São Paulo: Malheiros, 2008.

MENDES, Gilmar Ferreira. Curso de Direito Constitucional. 2. ed. rev. e atual. São Paulo, Saraiva, 2008/ BARROSO, Luís Roberto. O direito constitucional e a efetividade de suas normas. 9. ed. Rio de Janeiro, Renovar, 2009.

MI 107 Ementa e Acórdão. Disponível em: $<$ https://stf.jusbrasil.com.br/jurisprudencia/752372/mandado-de-injuncao-mi-107-df/inteiroteor-100468563?ref=juris-tabs>. Acesso em: 4 maio 2018.

MIRANDA, Jorge. Manual de direito constitucional. Tomo I, Coimbra: Coimbra Editora, 1997.

PIOVESAN, Flávia C. Proteção judicial contra omissões legislativas: ação direta de inconstitucionalidade por omissão e mandado de injunção. São Paulo: Editora Revista dos Tribunais, 1995.

VILANOVA, Lourival. A Dimensão Política nas funções do Supremo Tribunal Federal. In: Revista de Direito Público.

\title{
A HERMENEUTIC CONSTRUCTION OF THE INJUNCTION MANDATE BY THE SUPREME FEDERAL COURT UNDER THE OPTICS OF THE PRINCIPLE OF THE SEPARATION OF POWERS AND JUDICIAL ACTIVISM
}

\begin{abstract}
This paper aims to promote a constitutional analysis of the Injunction Mandate instituted as a remedy able to exercise the constitutional rights and freedoms, ensured by constitutional rules of limited effectiveness, which cluttered by the legislative omission to edit the regulatory norm. In this step, is tried to observe the process of construction of the effects that were conferred by the Federal Supreme Court through the decisions granting injunction, drawing a brief study about the institute and the interpretive currents that have on it, as well as showing the current position adopted by the Supreme Court. As a result, the supposed conflict between the principles of separation of powers and the effectiveness of the constitution will appreciate, due to
\end{abstract}


the process of activism adopted by the judiciary, which accuse of usurping the legislative function by exercising a political function. It is a bibliographical, doctrinal study, with brief jurisprudential analysis. Finally, it will be appreciated the relevance of judicial activism in the process of effectiveness conferred upon the writ of injunction that makes possible, therefore, effectiveness to the Constitution itself. It has concluded that judicial activism has positive effects in the legal system, as long as it respects the limits imposed by the Constitution, under penalty of contrary to a solution, become a problem.

Keywords: Injunction Mandate. Constitutional omission. Judicial Activism. 